https://doi.org/10.22363/2312-8674-2019-18-4-845-864

Научная статья / Research article

\title{
Russian-Chinese cooperation in Central Asia in the context of 'Belt and Road Initiative:' Historical retrospective and economic prospects
}

\author{
Stanislav E. Martynenko ${ }^{a}$, Nickolay P. Parkhitko ${ }^{a}$ \\ ${ }^{a}$ RUDN University; 6, Miklukho-Maklaya St., Moscow, 117198, Russia; \\ martynenko-se@rudn.ru, parkhitko-np@rudn.ru
}

\section{Российско-китайское сотрудничество в Центральной Азии в контексте инициативы «Один пояс, один путь». История и экономические перспективы}

\author{
С.Е. Мартыненко ${ }^{\text {a }}$ Н.П. Пархитько ${ }^{a}$

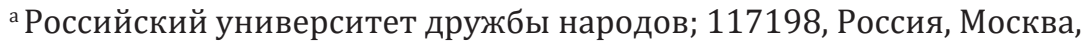 \\ ул. Миклухо-Маклая, 6; martynenko-se@rudn.ru, parkhitko-np@rudn.ru
}

\begin{abstract}
This article examines Russo-Chinese investment cooperation in China's Belt and Road Initiative (originally the Silk Road Economic Belt). At the same time, it also studies bilateral agreements, as well as investment and mechanisms. Another focus is the impact of the BRI in Central Asian countries on Russian interests in the region. Research is based on an analysis of the history of joint Russian and Chinese initiatives for economic development to determine the feasibility of cooperation in the BRI. Meanwhile, the authors discuss the BRI's impact on the economic and foreign policy of the two partners, as well as the risks and opportunities for Russia. The article is based on content and statistical analysis combined with a historical approach. It concludes that Russia and China are actively developing investment cooperation in the framework of the BRI, including the Silk Road Fund. The principal elements of the partnership involve the economy and processing and transporting energy resources. Its objective is to attain both regional economic stability as well as maximizing economic and political independence.-

Keywords: Russia, China, 'Belt and Road Initiative,' Silk Road Economic Belt, economy

Funding: This research was supported by the Russian Science Foundation. The scientific project № 19-18-00165.

For citation: Martynenko, Stanislav E., and Parkhitko, Nickolay P. "Russian-Chinese cooperation in Central Asia in the context of 'Belt and Road Initiative:' Historical retrospective and economic prospects." RUDN Journal of Russian History 18, no. 4 (November 2019): 845-864. https:// doi.org/10.22363/2312-8674-2019-18-4-845-864
\end{abstract}

Аннотация: В статье исследуется инициатива «Один пояс, один путь» (BRI, также называемая Экономическим Поясом Шелкового пути), предложенная Китаем в 2013 г. Особое внимание уделяется российско-китайскому инвестиционному сотрудничеству в рамках проекта. Также в материале наиболее детально представлены двусторонние соглашения и проанализированы

(C) Martynenko S.E., Parkhitko N.P., 2019

This work is licensed under a Creative Commons Attribution 4.0 International License https://creativecommons.org/licenses/by/4.0/ 
основные инвестиционные потоки и существующие инвестиционные механизмы. В статье рассматривается вопрос о реализации проекта «Один пояс, один путь» с участием стран Центральной Азии в контексте национальных интересов России в этом регионе. Новизна исследования основывается на анализе российских и китайских инициатив в исторической ретроспективе с целью выявления вероятности объединения российского и китайского видения нового глобального экономического развития, а также расширения сотрудничества по объединению совместных усилий в данном направлении. Также сделан краткий прогноз развития проекта в ближайшей перспективе. Авторы дают характеристику влияния проектов на российскую и китайскую экономику, а также на внешнюю политику двух стран. В статье также анализируются риски и возможности для России, связанные с реализацией проекта. В ходе подготовки исследования авторы использовали общенаучные и специальные методы: контент-анализ и статистический анализ, метод исторического анализа и историко-ретроспективный метод. При изучении проблемы были сделаны следующие выводы: в современной международной повестке дня Россия и Китай активно развивают инвестиционное сотрудничество в рамках проекта «Один пояс, один путь», в том числе с привлечением Фонда «Шелковый путь». Основными отраслями сотрудничества являются экономика, добыча и транспортировка энергоносителей. Глобальная задача - достижение экономической стабильности в регионе и в то же время - получение максимальной экономической и политической независимости от глобальной политической конъюнктуры.

Ключевые слова: Россия, Китай, Инициатива «Один пояс, один путь», Экономический Пояс Шелкового Пути, экономика

Финансирование: Исследование выполнено за счет гранта Российского научного фонда (проект №19-18-00165).

Для цитирования: Мартыненко С.Е., Пархитько Н.П. Российско-китайское сотрудничество в Центральной Азии в контексте инициативы «Один пояс, один путь». История и экономические перспективы // Вестник Российского университета дружбы народов. Серия: История России. 2019. Т. 18. № 4. С. 845-864. https://doi.org/10.22363/2312-8674-2019-18-4-845-864

\section{Introduction}

The Silk Road was a network of trade routes, formally established during the Han Dynasty. The road originated from Chang'an (now Xian) in the east and ended in the Mediterranean in the west, linking China with the Roman Empire.

As China's silk was the major trade product, German geographer Ferdinand von Richthofen coined it the Silk Road in $1877 .{ }^{1}$ It was not just one road but rather a series of major trade routes that helped build trade and cultural ties between China, India, Persia, Arabia, Greece, Rome and Mediterranean countries. It reached its height during the Tang Dynasty, but declined in the Yuan dynasty, established by the Mongol Empire, as political powers along the route became more fragmented. The Crusades in the fifteenth century as well as advances by the Mongols in Central Asia seriously disrupted the Silk Route. By the sixteenth century, commerce with Europe had largely shifted to maritime trade routes, which were then considered cheaper and faster. Today, Central Asian countries are unable to interact with other countries. They are keen to integrate with the world economy. They are members of WTO but are still heavily dependent on Russia. For example, remittances, which dropped from earlier figures to a mere 15 percent in 2014, were specifically due to Russia's economic woes. ${ }^{2}$ In the contemporary globalised world order connectivity and trade have come to occupy the centre stage

${ }^{1}$ Lee, A. "A brilliant plan. One Belt One Road," CLSA, accessed May 4, 2019, https://www.clsa. com/special/onebeltoneroad/.

2 McBride, James. "Building the New Silk Road," Concil on Foreign Relation, accessed May 4, 2019, http://www.cfr.org/asia-and-pacific/building-new-silk-road/p36573. 
of international politics. Recently, several connectivity projects have been launched. In this interplay of connectivity projects and North-South/East-West links, Central Asia occupies a key position. Central Asia's abundant natural resources and geopolitical location in the centre of the Eurasian heartland has attracted major powers who are vying for presence through such projects. ${ }^{3}$

From the historiographical point of view the problem of Russian-Chinese cooperation was the subject of interest of respectful Russian scientists such as S. Luzyanin, V. Mamonov, D. Teurtrie, V. Kolosov, M. Zotova, F. Popov, A. Gricenko, A. Sebencov, A. Larin, I. Makarov, A. Sokolova, D. Mosyakov, ${ }^{4}$ A. Mastepanov and others. They researched quite all the aspects and fragmentations of Sino-Russian relations: from economic to cultural and political ones.

Russian-Chinese relations are characterized by high dynamics of development, a solid legal base, an extensive organizational structure and active ties at all levels.

China and the USSR established diplomatic relations on October 2, 1949. The Soviet Union was the first foreign state to announce the recognition of the PRC.

After the collapse of the USSR, the Chinese government on December 24, 1991 recognized the Russian Federation as the legal successor of international rights and obligations of the former Soviet Union.

The basic principles and directions of bilateral cooperation are reflected in the Treaty of Good Neighborhood, Friendship and Cooperation between the Russian Federation and the People's Republic of China of July 16, 2001.

Today's Russian-Chinese relations are officially defined by the parties as a comprehensive equal trusting partnership and strategic interaction. An intensive political dialogue is ongoing. President of Russia V.V. Putin and President Xi Jinping meet annually at least five times a year.

Speaking about Russian-Chinese cooperation, we should mention the Agreement on Good Neighborliness, Friendship and Cooperation between the Russian Federation and the People's Republic of China, signed on July 16, 2001 in Moscow by Chinese President Jiang Zemin and Russian President Vladimir Putin, since this agreement laid the foundation for high-quality a new stage of partnership between the two states. ${ }^{5}$

\footnotetext{
3 Joshi Nirmala, Kamala Kumari, "China's Silk Road Economic Belt and the Central Asian Response," Russian International Affars Concil, accessed May 6, 2019, https://russiancouncil.ru/en/analytics-and-comments/analytics/china-s-silk-road-economic-belt-and-the-central-asian-response/.

${ }^{4}$ S.G. Luzyanin, “ 'Odin poyas, odin put':' rossiyskaya proyektsiya i problemy sopryazheniya," in Kitay v mirovoy i regional'noy politike. Istoriya i sovremennost' (Moscow: IDV RAN Publ., 2017), 27-37; S.G. Luzyanin, A.G. Larin, "Problema kitayskikh migrantov v Rossii v kontekste sopryazheniya 'YEAES Shelkovyy put"," in Kitay $v$ mirovoy i regional'noy politike. Istoriya i sovremennost' (Moscow: IDV RAN Publ., 2017), 64-76; V.A. Kolosov, M.V. Zotova, F.A. Popov, A.A. Gritsenko, and A.B. Sebentsov, "Postsovetskoe pogranich'e Rossii mezhdu Vostokom i Zapadom (analiz politicheskogo diskursa)," Polis. Political studies, no. 5 (2018): 57-69; I. Makarov, A. Sokolova, "Sopryazheniye yevraziyskoy integratsii i Ekonomicheskogo poyasa Shelkovogo puti: vozmozhnosti dlya Rossii," International Organization Research Journal 11, no. 2 (2016): 40-57; D.V. Mosyakov, "Novaya i noveyshaya istoriya: modernizaciya i globalizaciya vostochnyh obshhestv," International Trends 15, no. 3 (2015): 103-106; A. Mastepanov, and I. Tomberg, "Kitay diktuyet energeticheskuyu politiku XXI v.," International Trends 16, no. 3: 6-38.

${ }^{5} \mathrm{Li}$ Na. "Iniciativa 'odin poyas, odin put' kak novaya model' sotrudnichestva KNR s Rossiey $\mathrm{i}$ stranami Central’noy Azii,” RUDN Journal of World History, no. 10 (2018): 384-385.
} 
Russia and China share a number of common interests, not least in post-Soviet Central Asia. Beijing and Moscow are seeking to increase stability in the region and reduce the threat of separatism, notably in Xinjiang Province and (just recently) the North Caucasus. They both seek to limit the US presence in the region. In the economic sphere, both China and Russia want to increase ties in the region and ensure markets for their exports in the Central Asian economies. However, there are also sources of contention. Beijing is very interested in gaining direct access to Central Asian energy resources, while Moscow wants to maintain its dominant influence over the routes of energy supplies in the region. Despite some rival economic interests, they are a not potential source of conflict in the future, because there is much broader agreement on the need to cooperate on enhancing political and economic stability in the region.

In the past 50 years China has developed from a poor inward-looking agricultural country to a global manufacturing powerhouse. ${ }^{6}$ Its model of investing and producing at home and exporting to developed markets has elevated it to the world's second-largest economy after the USA.

Now faced with a slowing economy at home, China's leadership is looking for new channels to sustain its appetite for growth at a time when developing neighbors are experiencing rapidly rising demand.

At the heart of 'Belt and Road Initiative' (BRI) lies the creation of an economic land belt that includes countries on the original Silk Road through Central Asia, West Asia, the Middle East and Europe, as well as a maritime road that links China's port facilities with the African coast, pushing up through the Suez Canal into the Mediterranean. The project aims to redirect the country's domestic overcapacity and capital for regional infrastructure development to improve trade and relations with Asean, Central Asian and European countries.

First announced by Chinese president Xi Jinping in 2013, the core drive behind OBOR was clear. China's massive manufacturing sector, which had fueled its rapid expansion since the country's opening up in the 80 s, was reaching overcapacity relative to sluggish global demand. Its export growth rate had slowed by a third since its historical peak in 2006, according to World Bank data, weighed down by anemic global consumer confidence still recovering from the 2008 financial crisis and continuing Greek and other European sovereign debt and fiscal worries.

Meanwhile, China faced a domestic conundrum of its own. Investment accounted for nearly half of GDP at the time, twice the world average according to OECD data, and was running into sharply diminishing returns. ${ }^{7}$ This meant that rather than China consuming the fruits of its labor, more money was flowing into new real estate projects, businesses, machinery, etc. than could be productively used.

BRI would achieve several goals in one fell swoop. Connecting China more directly with European and wealthy Persian Gulf consumer markets would vastly reduce transport times and cost, breathing life into higher-end technology manufacturing deve-

${ }^{6}$ D.V. Mosyakov, "Novaya i noveyshaya istoriya: modernizaciya i globalizaciya vostochnyh obshestv," International Trends 15, no. 3 (2015): 103.

7 "China Economic Snapshot," OECD, accessed May 6, 2019, https:/www.oecd.org/economy/ china-economic-snapshot/. 
loping up and down the East Coast, Pearl River Delta, and increasingly inland (with China's Western Development strategy). This improved ability to get high-tech and finer products to market would drive up employment demand for their creators i.e. the engineers, designers, financiers, and everyone in between involved in China's burgeoning innovation economy. These high-value-added sectors would in turn provide the growing urban middle class with spending money, driving up the domestic consumption share of GDP to assuage economic concerns over the investment share. ${ }^{8}$

\section{The economic basis of the BRI project}

On 28 March 2015, during the Boao Forum for Asia, China's National Development and Reform Commission, in conjunction with China's Foreign Ministry and Commerce Ministry, issued an action plan for the Belt and Road, bringing the concept one important step closer to realization. Titled the 'Vision and Actions on Jointly Building Silk Road Economic Belt (SREB) and $21^{\text {st }}$ Century Maritime Silk Road,' the official document lays out the basic goals of the 'One Belt One Road' Initiative:

It is aimed at promoting orderly and free flow of economic factors, highly efficient allocation of resources and deep integration of markets; encouraging the countries along the Belt and Road to achieve economic policy coordination and carry out broader and more in-depth regional cooperation of higher standards; and jointly creating an open, inclusive and balanced regional economic cooperation architecture that benefits all. ${ }^{9}$

The Initiative's current priority is infrastructure connectivity. Towards that end, the Chinese government has facilitated the establishment of the Asian Infrastructure Investment Bank and set up a 40 billion US dollars Silk Road Fund.

SREB in geographically sense starts from China on the east end of the Eurasia continent, passes through Central Asia, West Asia, South Asia and some other regions by three lines (north line, middle line, and south line), approaches the Caspian, Black Sea, Mediterranean Sea and the Arabian Peninsula, and arrives in Europe and North Africa on the west end of Eurasia. Specifically, the three lines of the SREB are as follows:

- 'North Line' starting from China, via Kazakhstan, through southern Russia, through the Ukraine, Belarus, by Poland and other Eastern European countries, and finally reaches Germany, arriving in Western Europe;

- 'Middle Line' starting from China, via Kyrgyzstan, Tajikistan, Uzbekistan by Turkmenistan and continues along the south shore of the Caspian Sea, finally reaching Europe through Turkey;

- 'South Line' starting from China, via Afghanistan, Pakistan, through Iran into the Arabian Peninsula, and then reaches North Africa through Egypt. ${ }^{10}$

${ }^{8}$ Marcus Ryder, "One Belt, One Road, One Trillion Dollars - Everything You Need to Know in One Essay," CGTN.COM, accessed May 4, 2019, https://news.cgtn.com/news/3d63544d3363544d/share_p.html

9 "On the Formation and Significance of the Silk Road," CNKI.NET, no. 1 (2017), http://kns.cnki.net/ KCMS/detail/detail.aspx?dbcode $=$ CJFQ\&dbname $=$ CJFDLAST2018\&filename $=$ XWLL2017S1192\&uid=WEEvREcwSIJHSldTTEYzVDhsN3d4K3BWZHE1M1RqQk5wUVdiSWlvaDVOcz0=\$9A4hF_YAuvQ5obgVAqNKPCYcEjKensW4IQMovwHtwkF4VYPoHbKxJw!!\&v=MjM3MjdTN0RoMVQzcVRyV00xRnJDVVJMT2ZZdVJvRnk3aFY3ekFQVHJWXJHNEg5YXZybzVNWm9SOGVYMUxleFk.

${ }^{10}$ Silk Road Economic Belt: Prospects and Policy Recommendations. Working Papers, May 20, 2014, http://intl.ce.cn/specials/zxxx/201405/26/P020140526515434111874.pdf. 
One end of the SREB is the East Asian-Southeast Asia industrial chain, and the other end connects the developed Europe and the developing Africa. Even by the narrow-definition estimates, the SREB covers a population of 2.175 billion, accounting for $30.87 \%$ of the world's total population. It is also related to economic scale of about 16 trillion U.S. dollars, accounting for $22.1 \%$ of world total. By the broad-definition estimates, the SREB covers a population of approximately 3 billion, and relates to economy of approximately $\$ 23$ trillion USD, with huge market potential. ${ }^{11}$

China is backing the plan with considerable resources, setting up, as we mentioned above, a New Silk Road Fund of $\$ 40$ billion to promote private investment along BRI. The New Silk Road Fund is sponsored by China's foreign exchange reserves, as well as government investment and lending arms.

In addition, the Asia Infrastructure Investment Bank is widely expected to support the initiative with a considerable share of its $\$ 100$ billion in lending, and the China Development Bank reportedly said it would invest almost $\$ 900$ billion into more than 900 projects involving 60 countries to bolster the initiative. ${ }^{12}$ The OBOR goes well beyond infrastructure, envisioning closer coordination of economic development policies, harmonization of technical standards for infrastructure, removal of investment and trade barriers, establishment of free trade areas, financial cooperation and 'people to people bonds' involving cultural and academic exchanges, personnel exchanges and cooperation, media cooperation, youth and women exchanges, and volunteer services. ${ }^{13}$

BRI would achieve several goals in one fell swoop. Connecting China more directly with European and wealthy Persian Gulf consumer markets would vastly reduce transport times and cost, breathing life into higher-end technology manufacturing developing up and down the East Coast, Pearl River Delta, and increasingly inland (with China's Western Development strategy). This improved ability to get high-tech and finer products to market would drive up employment demand for their creators i.e. the engineers, designers, financiers, and everyone in between involved in China's burgeoning innovation economy. These high-value-added sectors would in turn provide the growing urban middle class with spending money, driving up the domestic consumption share of GDP to assuage economic concerns over the investment share.

There's a geopolitically vital addition to BRI's benefits: increasing the efficiency of land and maritime trade routes would share China's economic success with its peers near and far by geographically dispersing complex supply chains across national borders. Large projects up and down the supply chain are already starting to see needed

11 "The Impact of the New Silk Road on Trade: Analysis of Integration Model," CNKI.NET, no. 3 (2019), http://kns.cnki.net/KCMS/detail/detail.aspx?dbcode=CJFY\&dbname=CJFDLAST2019\&filename=DLCS201903019\&uid=WEEvREcwS1JHSldTTEYzVDhsN3d4K3BWZHE1M1RqQk5wUVdiSWlvaDVOcz0=\$9A4hF_YAuvQ5obgVAqNKPCYcEjKensW4IQMovwHtwkF4VYPoHbKxJw!!\&v=MTQ0OTkxRnJDVVJMT2ZZdVJvRnk3aFU3elBJU0hJZmJHNEg5ak1ySTIFY11SOGVYMUx1eFITN0RoMVQzcVRyV00.

12 China Development Bank data, accessed May 11, 2019, http://www.cdb.com.cn/English/Xwzx_ 715/khdt/201803/t20180309_4988.html.

${ }^{13}$ Bert Hofman, "China's One Belt One Road Initiative: What we know thus far," World Banck Grup, accessed May 11, 2019, http://blogs.worldbank.org/eastasiapacific/china-one-belt-one-road-initiative-what-we-know-thus-farK_ftnrefl. 
funding regardless of nationality. Chinese companies are investing massively in Central Asia's mining and petroleum industries, for example, improving employment conditions for substantial portions of their labor forces. And experienced Chinese high-speed rail companies, which have laid more track than the rest of the world combined, are building and planning networks in Southeast Asia and Africa (linking over sixty countries of the latter in conjunction with road construction projects). ${ }^{14}$

\section{The historical retrospective of the Russian-Chinese economic cooperation in Central Asian region}

Despite the collapse of the Soviet Union and China's growing economic influence in Central Asia, Russia keeps playing a substantial role in the region through a combination of energy, culture and military bonds that run too deep for China to severe in the short to medium term. ${ }^{15}$ China historically lags behind Russia in the matters of influence on Central Asia's humanitarian field.

Economically, while China has emerged as the region's number one trading partner and investor, Russia remains a dominant economic force in Central Asia. Russia continues to play a bigger role than China in the Central Asian oil market. Kazakhstan's two largest oil pipelines (with a combined export capacity of 1.42 million bpd) terminate on Russian territory, in Novorossiysk and in Samara. Tajikistan imports 90 percent of all petroleum products from the Russian Federation, while neighboring Kyrgyzstan brings in 92 percent of its fuel from Russia. Uzbekistan, with the region's largest population of 28 million people, consumes mostly internally produced natural gas but exports more than half of its remaining gas through Russia.

Russia's economic dominance in Central Asia is more prominent given the reliance of Central Asian countries on migrant remittance from Russia. About 1 million Kyrgyz citizens and over 1 million Tajikistan citizens (about half of each country's workforce) work in Russia. Tajikistan, a country with 8 million people, has been able to regain stability after the 1992-97 civil war, because many of its citizens are earning a living in Russia. The same goes for Kyrgyzstan, a country of less than 6 million and where two presidents have been overthrown since 2005. ${ }^{16}$ According to World Bank data, migrant remittance from Russia accounted for 25 per cent of the GDP in 2018 for both Tajikistan and Kyrgyzstan, and 12 per cent for Uzbekistan. ${ }^{17}$ While Russia's recent economic crisis and drop in the Ruble value has led to notable reduction of migrant remittance to these Central Asian countries, a significant portion of their GDP will continue to come from remittance from Russia given there is limited employment opportunities domestically and elsewhere, except Russia.

${ }^{14}$ Marcus Ryder, and Patrick Musgrave, "One Belt, One Road, One Trillion Dollars - Everything You Need to Know in One Essay," CGTN, accessed May 12, 2019, https://news.cgtn.com/news/3d63544 d3363544d/share p.html.

${ }^{15}$ Garret Mitchell, "China in Central Asia: the Beginning of the end for Russia?" SLOVO 26, no. 1 (2014): 7.

16 James Sherr, "How to Suborn Great Powers," Asia Policy, no. 16 (2013): 166.

17 "Russia's rouble crisis poses threat to nine countries relying on remittances," The Gardian, accessed May 12, 2019, http:/www.theguardian.com/world/2015/jan/18/russia-rouble-threat-nine-countries-remittances. 
Russia's ability to advance a Moscow-centered regional economic integration framework also promotes Russian economic supremacy over China in Central Asia. On the one hand, since 2003, the Chinese concept of SCO (Shanghai Cooperation Organization) free trade zone has not materialized because of the lack of support among member countries. ${ }^{18}$ On the other hand, in 2010 Russia successfully established a Moscowcentered Eurasian Customs Union which was upgraded in May 2014 to the Eurasian Economic Union (EEU). The EEU comprises members such as Russia, Belarus, Kazakhstan, Armenia and Kyrgyzstan (since 1 May 2015), and is open for Tajikistan and even Turkey to join this organization. The objective of the EEU is to establish a bloc of post-Soviet republics and to create a single market for goods and services among members. ${ }^{19}$ Taking into consideration both economic and political aspects, the EEU could serve as a potential counter-balance to Sino-Central Asian economic ties.

In the political and security arena, Russia's dominance is even clearer. Five Central Asian states were all founding members of the Russian-centered Commonwealth of Independent States (CIS). Member countries interact within the CIS through its coordinating institutions such as Council of Heads of State, the Council of Heads of Government and the Councils of Foreign Ministers and Defense Ministers to promote regional cooperation on various issues. On the CIS platform Russia has enhanced its leading military role establishing the Collective Security Treaty Organization (CSTO) in the post-Soviet space including Central Asia. In recent years Russia has expanded defense capabilities, legal mandate, and a range of CSTO missions in the region. At the forefront of these efforts is a Russia-led plan to create a new CSTO Rapid Reaction Force (RRF) and a larger Central Asian Military Group. ${ }^{20}$ As CSTO is evolving into a more coherent organization, American political scientist Jeffrey Mankoff argues that political and security integration via CSTO 'provides Russia an avenue for direct intervention in Central Asia. ${ }^{21}$ Withdrawing NATO from Central Asia after 2014 further enhanced the Russia-led $\mathrm{CSTO}$ as the dominating security force in the region. In comparison, the China-centered SCO does not provide any security presence in Central Asia.

Lastly, the biggest advantage of Russia in Central Asia is supported, perhaps, by the fact that Central Asia represents one of the unique locations in the world, where Russia successfully implements instruments of soft power. Russian language is dominant in Central Asia and many of the Central Asian elites were educated in Russia and have developed close connections with Russian leaders. According to the last Soviet census, conducted in 1989, as a result of the USSR collapse about 25 million ethnic Russians

${ }_{18}$ Yu Bin, "China-Russia Relations: Putin's Glory and Xi's Dream. Comparative Connections," PACFORUM.ORG, Vol. 3, accessed May 11, 2019, https://csisprod.s3.amazonaws.com/s3fspublic/legacy_files/files/publication/1303qchina_russia.pdf.

19 "The New Eurasian Economic Union - A China FTA in the Offing?" China Briefing, accessed May 12, 2019, http:/www.china-briefing.com/news/2015/01/09/new-eurasian-economic-union-china-ftaoffing.htmlKsthash.AY2bpMUX.dpuf.

${ }^{20}$ Zhang Hongzhou, "Building the Silk Road economic Belt: Problems and Priorities in Central Asia," Policy Report, accessed May 12, 2019, https://www.rsis.edu.sg/wp-content/uploads/2015/05/PR150518_ Building-the-Economic-Silk-Road-Belt.pdf.

21 Jeffrey Mankoff, “The United States and Central Asia in 2014," CSIS Report, accessed May 11, 2019, https://www.csis.org/analysis. 
found themselves outside the borders of the Russian Federation, on the territory of new independent states. ${ }^{22}$ While the number of ethnic Russians residing in Central Asia has notably decreased since the collapse of the Soviet Union, their combined total currently stands at about 6,5 million. The vast majority continues to live in Kazakhstan - about 3,5 million Russians (representing 19 percent of the country's total population). ${ }^{23}$ Ethnic Russians make up 12 percent of the population in Kyrgyzstan, 6 percent in Uzbekistan, 4 percent in Turkmenistan and 1 percent in Tajikistan. ${ }^{24}$

The 'soft power' tools used by Russia in the Central Asian region are worth to be mentioned separately. One of the key actors in the field of Russian 'soft power' is Rossotrudnichestvo - the Federal Agency for the Commonwealth of Independent States, compatriots living abroad. It is the agency for international humanitarian cooperation. It was established in September 2008 and is structurally subordinated to the Russian Foreign Ministry. Rossotrudnichestvo, as the name of the organization implies, promotes international humanitarian cooperation and, together with the Russian Foreign Ministry, represents modern Russia abroad. Currently, the organization has 95 offices in 79 countries, 72 Russian centers of science and culture in 62 states and 23 representatives of the Agency as part of Russian embassies in 22 countries, including Latin America, North America, Europe, Africa and Asia. ${ }^{25}$ Nevertheless, its activities are mainly focused on the CIS member states within the Russian centers of science and culture in each country.

One of the key areas of Russia's implementation of 'soft power' in the region is the promotion and support of the Russian language. The federal target program 'Russian Language' for 2016-20 is a strategic element in the implementation of this task. Practical work in this direction is carried out through the Russian centers of science and culture (RCSC).

During 2014-18 79 RCSC offices together with the Ministry of Education and Science of Russia and the Russian Language Institute A.S. Pushkin on an ongoing basis conducted various cultural, educational, scientific and methodological events and projects. For students of the Russian language, access to the My Russian electronic library is provided, which includes more than 186 thousand titles of various publications, including educational literature. Russian Language Day is widely celebrated with the support of the RCSC in the framework of more than 500 events held in Kazakhstan, Kyrgyzstan, Uzbekistan and Tajikistan. In total, with the assistance of Rossotrudnichestvo in 2018 alone, more than 3 thousand comprehensive events were held aimed at supporting and popularizing the Russian language abroad. ${ }^{26}$

22 D. Teurtrie, "Russkiy vopros v postsovetskiy period," Vestnik of Saint Petersburg University. History 62, no. 1 (2017): 44.

23 “Chislennost' naseleniya Respubliki Kazakhstan po otdel'nym etnosam na nachalo 2019 goda," Open Data. Gov, accessed May 12, 2019, https://data.egov.kz/datasets/view?index=kazakstan_respublikasy_halkyny.

24 "Major ethnic groups in Central Asia," National Security, accessed May 12, 2019, http://www. nationalsecurity.ru/maps/centralasiaethno.htm.

25 "Predstavitel'stva Rossotrudnichestva v mire," Study in Russia, accessed May 12, 2019, https:// studyinrussia.ru/upload/embassy/\%D0\%9F\%D1\%80\%D0\%B8\%D0\%BB $\%$ D0\%BE $\%$ D0 $\%$ B $6 \%$ D0 $\%$ B5\%D0\%BD $\%$ D0\%B8\%D0\%B5-1.pdf.

26 “Report «On the Results of Activity of Rossotrudnichestvo for 2018," Rossotrudnichestvo, accessed May 12, 2019, http://rs.gov.ru/uploads/document/file/11228/\%D0\%94\%D0\%BE\%D0\%BA\%D0\%BB\%D0\% B0\%D0\%B4\%202018\%20\%D0\%B3\%D0\%BE\%D0\%B4.pdf. 
Concerning the objectives of the state programs 'Foreign Policy' and 'Development of Education,' implementation of state support concepts and Russian language and 'Russian School Abroad' promotion, Russian education abroad is being actively promoted. For example, the practice of facilitating the holding of educational exhibitions and fairs in the CIS has proved to be very positive. In Central Asia, the most large-scale event in 2018 was the VIII International Exhibition-Fair 'Russian Education. Dushanbe-2018,' held in April 2018 in the capital of Tajikistan with the participation of 35 educational organizations from Russia and the CIS. ${ }^{27}$

For Russia, these issues are particularly acute: the region of the post-Soviet borderlands stretched across the periphery of the former USSR in a broad band. After the collapse of the Soviet Union, the political and everyday vocabulary was instantly filled with tenacious, spatially determined categories: 'near abroad,' preserving the memory of the allied border as a sacred furthest limit of the Russian state space, emphasizing the immanent integrity of the region, and, as a result, the instability of the political boundaries cut in it. ${ }^{28}$

\section{Russian security interests in the context of the BRI project}

Russia officially endorsed EEU-Belt cooperation in May 2015, after a period of nearly two years of assessment, through a joint statement signed by President Vladimir Putin and President Xi Jinping. To obtain a better understanding of what shifted in Russia's strategic calculus, it is essential to briefly discuss Russia's global economic orientation more broadly.

Russian intentions to balance its economic trade dependence between Europe and Asia have been mooted since at least 1996. The Ukraine crisis, which was followed by sanctions, economic fallout and a sharp decline in oil prices, has accelerated Russia's 'turn to the East'. This policy seeks to improve economic integration with the AsiaPacific region and, in relative terms, decrease Russia's dependence on the West. So far, China's large economy has been the focal point of this policy, as the other major economies in the Asia-Pacific region, Japan and South Korea, are US treaty allies, and trade with ASEAN is negligible. China has steadily been working on integration with Russia through bilateral and multilateral institutions since the 1990s. The Belt may yet be another platform to further deepen cooperation and integration between China and Russia, and discussions on the specifics of EEU-Belt cooperation are ongoing - albeit slowly.

Moreover, Russia believes that the world order is moving towards economic and security macro-blocs. ${ }^{29}$ In western side Russia sees the EU and the TPIP; in the east it meets the TPP; and to its southeast, Russia faces the BRI. With the exception of the BRI, Russia finds itself excluded from all the other aforementioned economic blocs. The EEU, formally founded in 2014, is intended to serve Russia's own global economic

27 “Report «On the Results of Activity of Rossotrudnichestvo for 2018,” Rossotrudnichestvo, accessed May 12, 2019, http://rs.gov.ru/uploads/document/file/11228/\%D0\%94\%D0\%BE\%D0\%BA\%D0\%BB $\%$ D0 $\%$ B0\%D0\%B4\%202018\%20\%D0\%B3\%D0\%BE\%D0\%B4.pdf.

${ }_{28}$ V.A. Kolosov, "Postsovetskoe pogranich'e Rossii mezhdu Vostokom i Zapadom (analiz politicheskogo diskursa)," Polis. Political studies, no. 5 (2018): 57.

${ }^{29}$ M. Duchâtel, "Eurasian integration: caught between Russia and China," European Council on Foreign Relations, http://www.ecfr.eu/article/essay_eurasian. 
interests in much the same way. The creation of the EEU is the end result of numerous attempts to create a customs union and a single economic space since the early 1990s. Formally, it is the successor of the Eurasian Economic Commission (EEC) and its Customs Union. The EEU has the objective to give Russia and the former Soviet states of Armenia, Belarus, Kazakhstan, Kyrgyzstan and Ukraine a degree of economic latitude and sovereignty in world economic affairs. As a Russia-led initiative, it both results from and strengthens Russia's continued leverage over these former Soviet states. This has always been a top foreign policy priority for Russia. The EEU was also introduced as the result of a realization and decision in Russia that it should look beyond the mere transit potential of its own territory, and Central Asia's for that matter, to connect China, Europe and the Middle East through the Belt and other mechanisms. ${ }^{30}$

Nonetheless, the EEU has three serious limitations that have caused Russia to link it to the Belt: (a) it is regional and protective rather than extra-regional; (b) it is exclusive in membership; and (c) it carries limited economic weight. With the exception of Russia, all member states are landlocked. Excepting Russia and Kazakhstan, all member states have rather small economies. The aggregate GDP of Armenia, Belarus and Kyrgyzstan combined is only 5.4 per cent of that of Russia and only 19.4 percent if Kazakhstan is added. ${ }^{31}$ This gives Russia an overly central role. The economies of Russia and Kazakhstan are dominated by natural resources export and therefore lack complementarity - as the EEU does as a whole. Intra-EEU trade is thus of little significance to Russia. EEU total trade with third countries was at a mere 3.7 percent of world export and 2.3 percent of world import in $2014 .^{32}$

Thus, Russia cannot rely on either the size or economic clout of the EEU combined markets to advance its economic interests. Instead, it has to rely on Asian and European markets and on external investment in EEU markets. This is where the Belt comes into the discussion. In conversation with the authors in Moscow, there was a consensus among many experts (but not all) that the Belt supplements the EEU. Russia is interested in improving the competitiveness of EEU industrial output and strengthening the collective market, and through the Belt, China can provide the investment capital to make this happen. However, there is no consensus among international scholars about whether the Belt and the EEU's diametrically opposite institutional designs (the former is exclusive and regional in design, while the latter is inclusive and extra-regional) will actually supplement one another or work in opposition. Yet, the political will to connect the two is present and Russian and Chinese experts, at least, expect this to lead to practical cooperation.

What specifically shaped this political will in Russia? The Belt serves Russian interests in eight specific ways:

1. Linking up with the Belt gives the EEU legitimacy and international recognition by a great power, namely China-the first to do so;

30 I. Safranchuk, "Russia in a reconnecting Eurasia: foreign economic and security interests," in Centre for Strategic and International Studies (CSIS) (New York; London: Rowman \& Littlefield Publ., 2016).

31 "Calculations based on data derived from the World Bank," The World Bank, accessed May 14, 2019, www.data.worldbank.org/indicator/NY.GDP.MKTP.CD.

32 "Statistics on the official EEU website," Eruasian Economic Union, accessed May 14, 2019, www.eaeunion.org/?lang=enKabout. 
2. EEU-Belt cooperation accelerates Russia's 'turn to the East', thereby reducing Russia's economic and institutional dependence on the West;

3. Since China is economically more powerful than Russia in bilateral terms, negotiations through the Belt and EEU framework give Russia an edge;

4. The Belt undermines the relevance of US aid and integration efforts in Central Asia that bypass Russia, such as the US-proposed 'New Silk Road.' Another feature of the implementation of the SREB in the Russian-Chinese projection is associated with the beginning of reformatting intergovernmental economic and integration links to the construction of the 'Eurasian world' without the intervention of the United States and its close allies. In the context of Western anti-Russian sanctions and attempts to isolate the Russian Federation from the rest of the world, the convergence of the SREB, the EAEU and the new members of the SCO objectively 'torpedoes' the American strategy; ${ }^{33}$

5 . The Belt paves the way for closer cooperation with China, despite strategic distrust: linking it with the EEU sends a strong signal of trust to China, and is an additional institutional platform that may mitigate confrontation perspectives;

6. Russia views the Belt as an opportunity to bring in investment capital that will result in domestic and Central Asian job creation, which in turn may help to sustain order and stability in the face of the rising threat of Islamic extremism, the danger of 'color revolutions,' and instability radiating from Afghanistan. The stability of current Central Asia regimes and borders is of paramount interest to Russia; ${ }^{34}$

7. The economic interplay between the Belt and the EEU is anticipated to strike a balance between globalism and regionalism: Central Asian elites want to attract large capital to increase rent-seeking practices, while their populations favor employment creation and a measure of protectionism. ${ }^{35}$ With the open connectivity of the Belt presenting globalization opportunities and the regional market focus of the EEU, the merging of the two may possibly present a balance for Central Asia - it remains to be seen how this will unfold;

8. Russia considers the Belt as a mechanism to increase the EU's dependence on Russian energy as Central Asian energy resources are diverted to China.

Nevertheless, despite these convergences, it would appear as if the two initiatives of the EEU and the Belt are somewhat unnaturally coupled. Furthermore, Russia has been cautious in opening up infrastructure projects to Chinese parties and in specifying the terms of investment. Currently, both sides are working on forging an essential regulatory framework for trade and investment. ${ }^{36}$ This may be a slow process and Chinese investment in Russia remains relatively small.

${ }^{33}$ S. Luzyanin, "Odin poyas, odin put' : rossiyskaya proyektsiya i problemy sopryazheniya," in Kitay v mirovoy i regional'noy politike. Istoriya i sovremennost' (Moscow: IDV RAN Publ., 2017), 29.

${ }^{34}$ T. Bordachev, "Rossiya i Kitay v Central'noy Azii: bol'shaja igra s pozitivnoy summoy," Russia in Global Affairs Journal, http://www.globalaffairs.ru/valday/Rossiya-i-Kitai-v-Tcentralnoi-Azii-bolshaya-igra-s-pozitivnoi-summoi-18258.

35 V. Vorobyev, "Stykovka na strategicheskoy orbite," Russia in Global Affairs Journal, http:// www.globalaffairs.ru/number/Stykovka-na-strategicheskoi-orbite-18347.

36 “Interv'yu Posla Rossii v KNR A.I. Denisova informagentstvam 'Rossiya segodnya' i TASS," MID, accessed May 15, 2019, http:/www.mid.ru/en/web/guest/nota-bene/-/asset publisher/dx7DsH1WAM6w/ content/id/2327002. 
The question also remains whether an increased Chinese economic footprint in Central Asia will erode Russia's influence in the region over the long term, as Russia simply does not have the economic and financial means to compete with China. Yet for now, there is a 'division of labor': Russia maintains its strong military and political ties, while China injects financial capital into the region and increases its trade with the region. ${ }^{37}$ How this dynamic will play out in practice remains to be seen but is clear that China cannot compete with Russia's political, historical and cultural affinity with the region, and its domination of the region's military architecture.

However, this compartmentalization is not as rigid as it may sound. Russia is the main export destination for Central Asian labor resources and will remain in that role for the foreseeable future. This creates very strong economic dependence and generates considerable soft power. Kazakhstan, for example, conducted more trade with Russia than with China in 2016. At the same time, China is gradually increasing its security role in the area through significant arms sales to Kazakhstan, Turkmenistan and Uzbekistan. ${ }^{38}$

Some Russian analysts have expressed concerns that the Belt will, over time, subsume the EEU, as the Belt offers EEU members favorable incentives, specifically capital and better integration with the world economy. Concurrently, there is concern over Russian economic overdependence on China, as a result of which Russia is attempting to connect the EEU with Mongolian and South Korean regional integration initiatives and is seeking warmer ties with Japan. Indeed, Russia's 'turn to the East' has put it in a political and economic position of precarious overdependence on China - this is unlikely to be sustainable and is likely to affect Russian security interests negatively over time.

The interlinking of the EEU and the Belt is still unfolding, but it has already brought Russia and China closer.

\section{Historical prospects for the Russian-Chinese cooperation in the frames of the BRI project}

Russian-Chinese cooperation and large joint projects under the Belt and Road Initiative have stepped up across the energy, finance, high-speed rail, infrastructure and science and technology sectors over the past decade, which turns the rhetoric of partnership between China and Russia into tangible benefits.

Let's list the basic elements of the cooperation.

1. Economic ties. Even according to the narrow-definition, countries along the Belt bear a significant share of world international trade and cross-border capital flows. They account for $23.9 \%$ of the world's total exports of goods and services, $22.1 \%$ of world's imports of goods and services, and $25.7 \%$ of FDI inflows. ${ }^{39}$

Russia is an important supporter and participant in the process of promoting the BRI. In 2015 China and Russia signed the 'Joint Statement on Cooperation on the

${ }^{37}$ F. Lukyanov, "Kak Moskva ishhet svoe mesto v Central'noy Azii," Russia in Global Affairs Journal, http://www.globalaffairs.ru/redcol/Kak-Moskva-ischet-svoe-mesto-v-Tcentralnoi-Azii-18328.

38 Yezhegodnik SIPRI. Vooruzheniya, razoruzheniye i mezhdunarodnaya bezopasnost' (Moscow: IMEMO RAN Publ., 2018, https://www.imemo.ru/files/File/ru/publ/SIPRI/SIPRI_YEARBOOK_2017_RUS.pdf.

39 "Silk Road Economic Belt: Prospects and Policy Recommendations. Working Papers," China Economic Net, accessed May 15, 2019, http://intl.ce.cn/specials/zxxx/201405/26/P020140526515434111874.pdf. 
Construction of Joint Eurasian Economic Union and the Silk Road Projects.' China intends to connect an economically active, rapidly developing East Asia with rich, developed Europe with the help of the Silk Road Economic Belt, and Russia and Central Asia stand to serve as the central zone and hub. So China needs strategic cooperation with Russia in order to move ahead, to Europe through Russia and the countries of Central Asia. At the same time, Europe is the largest trading partner of Russia and for its economic development, Russia needs to implement interconnection and simplify its process of trade and investment with Europe. It is the gradual coupling of interests that stimulates Russia's active and constructive participation in the Chinese initiative and contributes to the further deepening of the confluence between the construction of the Silk Road Economic Belt and the Eurasian Economic Union. In May 2017, during the first Belt and Road Forum on international cooperation, Russian President Vladimir Putin gave an active cooperative signal and expressed hope that the Northern Sea Route would be connected with the BRI. In January 2018, China published a White Paper on China's Arctic policy, which reflects the country's readiness to build the 'Ice Silk Road' along with all interested parties, based on the development and use of the Arctic route. This is also China's active response to Russia's participation in Beijing's Belt and Road initiative. The Northern Sea Route is the shortest route connecting Asia and Europe. Chinese-Russian joint construction of an 'Ice Silk Road' could provide a new option for the interconnected relationships on the Eurasian continent, while at the same time it will intensify the economic development of the Northeast of China, Russia's Far East and Siberia. ${ }^{40}$

There is also one project that can be related to the mega-initiative and claim to have the strategic meaning. It is the hypothetic 'Synergizing' China's Belt and Road Initiative (BRI) and Russia's Eurasian Economic Union (EAEU). This idea arose in May 2015, a few months after the EAEU was officially established. Chinese leader Xi Jingping was in Moscow to attend the 70-th anniversary of Victory in the Great Patriotic War. Xi and Russian President Vladimir Putin reportedly agreed at the time to

connect the initiative of the construction of the Silk Road Economic Belt put forward by the Chinese side with the construction of the Eurasian Economic Union (EEU) of the Russian side. ${ }^{41}$

When convenient, the linking of the BRI and the EAEU is mentioned by Russian and Chinese leaders. In perspective this project may generate in the mind the image of two global giants hitching together their prized economic projects. In the subsequent years, however, here hasn't been much clarity on what either side really means when they mention this connection, because the components (EEU and BRI) of the hypothetic project have still not been complete in the full scale.

${ }^{40}$ Xing Guangcheng, Wang Xuemei, "Russia Supports the Chinese Belt and Road Initiative," Valdai Club, accessed May 15, 2019, http://valdaiclub.com/a/highlights/russia-supports-the-chinese-beltand-road/.

41 'Can Russia and China 'Synergize' the Eurasian Economic Union and the Belt and Road Initiative?” The Diplomat, accessed May 15, 2019, https://thediplomat.com/2018/11/can-russia-and-china-synergize-the-eurasian-economic-union-and-the-belt-and-road-initiative/. 
2. Logistics (transport cooperation). The transportation infrastructure of the Silk Road Economic Belt includes railways, roads, air transportation and pipelines, etc. After several decades of development, it has formed a comprehensive, three-dimensional traffic network. The northline of Silk Road is of specific interest for the authors, because about 25 percent of its length locates on the Russian territory. Railways go through China, Kazakhstan, Russia, Belarus, Poland and Germany and can constitute a route connecting Europe and Asia. This route is known as the 2nd Eurasia Land Bridge. ${ }^{42}$

3. Energy and pipeline cooperation. China in the world energy reserves, ranks among the forefront, both as the world's second energy producing country, is also ranked second in energy consumption in the country. As the economy continues to expand, China's energy consumption has continued to rise, China's rapid economic growth cannot do without Russian energy supplies, as energy reserves, production and export volume ranking the forefront of Russia, is China's major energy-importing item. Russia is a world energy superpower, the 2018 oil proven reserves in the world rankings ranked sixth, accounting for the world of 13 percent, oil production accounted for the world total output of 12 percent. ${ }^{43}$ Improving energy efficiency and ensuring the country's energy security are also among the priorities of both components (internal and external) of China's energy policy. ${ }^{44}$

As an example, we can give the following: about two thousand Chinese workers participated in the Eastern Siberia - Pacific Ocean gas pipeline at its part in Yakutsk. They also worked on the construction of the NPP Summit facilities in Vladivostok. This allowed both sides to accumulate experience in using Chinese labor at large construction sites. ${ }^{45}$

In Silk Road Economic Belt, Russia, Central Asia and Middle East are rich in oil and gas resources, and the pipeline transportation is highly developed. Russia, Middle East and Europe have established dense oil and gas pipeline network. Besides, there are several multinational oil and gas pipelines in the Silk Road Economic Belt.

Russia is not only oil-rich, gas reserves also ranked in the world. In 2014 Russian natural gas total export volume up to 1812 billion cubic meters, in 2015 the growth of $4.9 \%$, up to 1900 billion cubic meters. In 2015 China's natural gas imports amounted to 621 million cubic meters, which imports from Russia about 61 billion cubic meters. In the natural gas fields of cooperation, in Chinese-Russian consultations, the two countries will be on the West line gas project restarted, which is following the East line natural gas cooperation project reached remarkable results. China and Russia West line gas project of scale with the East line of the project comparable. The West line gas project

42 Silk Road Economic Belt: Prospects and Policy...

${ }^{43}$ Xuefeng Zhang, and Melebayev Serdar, "Analysis of Oil and Gas Cooperation between China and Russia in the Belt and Road," SHS Web of Conferences, accessed May 16, 2019, https://www.shs-conferences.org/articles/shsconf/pdf/2017/07/shsconf_ies2017_01034.pdf.

44 A. Mastepanov, and I. Tomberg, "Kitay diktuyet energeticheskuyu politiku XXI veka," International Trends 16, no. 3 (54) (2018): 18.

45 S. Luzyanin, and A. Larin, "Problema kitayskikh migrantov v Rossii v kontekste sopryazheniya YEAES - Shelkovyy put'," in Kitay v mirovoy i regional'noy politike. Istoriya i sovremennost' (Moscow: IDV RAN Publ., 2017), 66. 
cooperation reached with the East line natural gas project Double sword combination, this will promote 'One Belt and One Road' by the country's economic take-off. ${ }^{46}$

Europe and the United States who provoked the Ukrainian issue and implemented anti-Russian economic sanctions aimed at making pressure on the Russian government, shifted Russian attention to the East. In November 2014, covering from Siberia to the construction of China gas pipeline, including a 30 year gas supply contract, the Russian-Chinese joint efforts acquired a qualitatively new impulse.

\section{Problems and challenges}

Although the prospects for cooperation in the Silk Road Economic Belt can be anticipated, it still faces a lot of challenges involving international and domestic, political and economic aspects. Only by taking positive, reasonable and proper measures can the vision of construction of the Silk Road Economic Belt be achieved.

Above, we described the countries covered by the north line of the Silk Road Economic Belt. Most parts covered by North line are located in Eastern and Western Europe, and except Kazakhstan, these areas have higher development and better infrastructure, for example, freight railroad has been opened from China to Western Europe. The regions covered by the middle Line and south line include Central Asia, West Asia, North Africa and other regions. These regions are characterized with a poor natural environment, complex terrain conditions and low level of development. It will be very difficult to build railways, highways and other infrastructure connecting these countries. These objective conditions will be largely hindered the process of building a Silk Road Economic Belt and reduce the economic welfare of the entire project.

Vast areas of Silk Road Economic Belt are located in the three continents with a key strategic position and huge reserves of oil and gas resources. The proposal of building Silk Road Economic Belt will inevitably cause vigilance of traditional powers in these regions. It needs to promote economic prosperity and achieve mutual benefit and win-win results along the Road, and thus dispel suspicion and enhance mutual confidence.

The Russian concerns about the side effect of the project are also to be taken into consideration. It is really hard to expect Russia to open its Far East as completely as China's Shenzhen did. As Chinese economic and political expert Li Yonghui argues,

for a country like Russia, which puts security assurance over economic benefits, it is reasonable to see Russian Federation close itself in the future once they detect any adverse factors against its security or ecosystem. ${ }^{47}$

Russia's degree of openness may also be challenged by raised anxieties and tensions among local residents. An influx of Chinese investment may even amplify xenophobic sentiments among Russian nationalists.

${ }^{46}$ Xuefeng Zhang, Melebayev Serdar, Analysis of Oil and Gas Cooperation between China and Russia in the Belt and Road, https://www.shs-conferences.org/articles/shsconf/pdf/2017/07/shsconf_ies2017_01034.pdf

47 “Sino-Russian Cooperation, Exchange Increase Under Belt and Road Initiative," Sputnik News, accessed May 17, 2019, https://sputniknews.com/analysis/201803161062581637-china-russia-cooperationincrease-belt-and-road/. 
A rise in Chinese migrants to the Far East - a side effect of Chinese investment - is reportedly perceived by locals as a threat of China's population expansion. There is a common concern in Russia that the Far East might be 'Sinicized' after a massive arrival of Chinese capital, technology and services. There is a claim that the economic Sinicization may, sooner or later, set the stage for the erosion of geopolitical control. Others fear that China's exclusive economic penetration of Russia may turn it into a 'raw material appendix' of China.

It is also worth mentioning that not all states support China's initiative. India is wary of the SREB due to concerns that it could strengthen China's influence in the Indian Ocean. India also opposes the construction of the railway and pipeline because of their impact on the disputed region of Kashmir. The development of the project directly touches upon the interests of the ASEAN countries. ${ }^{48}$

\section{Conclusions}

The main conclusions we have revealed proceed from both political and economic principles. First of all, Russian Federation regards geographic position of the country as very attractive for linking Eurasia's two economic powerhouses: the European Union and East Asia. The connectivity dimension of the BRI, which seeks to improve land-based transportation links between the EU and China, is naturally aligned with Moscow's desire to unlock its transit potential in Eurasia. Of all the overland pathways between western China and Europe, the one through Russia is the shortest. Moreover, the Eurasian Economic Union (EEU) of Armenia, Belarus, Kazakhstan, Kyrgyzstan, and Russia allows cargo to pass through just two customs posts en route from Xinjiang to the EU's doorstep in Poland, Finland, or the Baltic states. Thanks to policy incentives provided by China, this route is now booming, with the volume of cargo transit growing by double digits every year since 2015. In the first ten months of 2018 alone, the volume of goods transported between China and Europe via Russia grew by 23 percent to 323,000 TEU (twenty-foot equivalent unit, a measure of ship cargo). ${ }^{49}$

So far, this trade is using existing railroads and highways. Moscow and Beijing are discussing projects for upgrading and expanding existing transportation links, including a high-speed rail connection between Moscow and Kazan with possible expansion to Europe and China, a highway from the Kazakhstan-Russia border to Europe, and several smaller projects to address existing bottlenecks. ${ }^{50}$ For Russia, upgrading the Trans-Siberian Railway is also a major priority, but it is of less interest to China. At the same time, Moscow has realized that a trans-Eurasian route from China to Europe via Kazakhstan and Russia is not a challenge to the Trans-Siberian Railway since these two routes target two different cargo bases in different regions of Asia.

${ }^{48}$ I. Makarov, and A. Sokolova, "Sopryazheniye yevraziyskoy integratsii i Ekonomicheskogo poyasa Shelkovogo puti: vozmozhnosti dlya Rossii," International Organizations Research Journal 11, no. 2 (2016): 55.

49 "Posol Rossii v KNR: rossiysko-kitayskoye sotrudnichestvo - stabiliziruyushchiy faktor v nyneshnem turbulentnom mire," Interfax, accessed May 17, 2019, https://www.interfax.ru/interview/645268.

50 “Moskva-Kazan' - pervyy shag v global'nom transportnom proyekte. RZHD, OAO 'Skorostnyye magistrali', , High-Speed Railway, accessed May 17, 2019, http://www.eng.hsrail.ru/press-center/news/178.html 
Beijing is also interested in developing infrastructure along the Northern Sea Route that passes through the Arctic along the Siberian coast. For Moscow, opening the route is both a major economic opportunity and a security challenge, and it is likely to proceed with some caution. So far Moscow has accepted Beijing as its principle partner in developing the Arctic. That seems quiet logical from the geopolitical point of view. Many economic activities that Russia wants to pursue in the region are subject to Western sanctions.

One example of Sino-Russian cooperation that is directly linked to the BRI is Chinese participation in Yamal LNG, the first liquefied natural gas (LNG) project in Russia above the Arctic Circle. In 2015, the Silk Road Fund (SRF), a special purpose vehicle created by Beijing to finance BRI projects, was able to acquire a 9.9 percent stake in Yamal LNG. ${ }^{51}$ Beijing later helped it secure a $\$ 12$ billion loan from China Export-Import Bank and China Development Bank. ${ }^{52}$ The China National Petroleum Corporation (CNPC), China's largest state-owned enterprise in the energy field, already had a 20 percent stake in Yamal LNG, bringing Beijing's total share in this strategic project to 29.9 percent. $^{53}$ Significantly, Yamal LNG is under U.S. sanctions, since one of its Russian shareholders, Gennady Timchenko, was put on the U.S. Treasury's special designated nationals (SDN) list, and the legal entity, Novatek, is included in the sectoral sanctions identification list. Without Chinese loans and equity financing provided through the BRI, Russia would have faced tremendous difficulties to complete this project, which acquires a strategic character concerning the global competition in the energy market.

Another example of Russia using BRI-related Chinese financial institutions to go round Western sanctions and attract investment to key projects is the SRF's decision in 2016 to acquire 10 percent in Sibur, Russia's largest petrochemical company. This built on Chinese petrochemical giant Sinopec's previous acquisition of 10 percent of Sibur. ${ }^{54}$

Outside of the high profile deals that were blessed by the top leaders of Russia and China, many smaller investment projects in Russia that lack powerful political backing struggle to attract Chinese investment. This causes some frustration among Russian private businesspeople about the opportunities provided by the BRI. However, the Russian government is fully aware that the low rate of Chinese investment in Russia is caused by the structural problems of the Russian economy and resultant lack of trust by Chinese businesses. The government views the BRI as a good framework to address at least the latter issue.

Summarizing all the above analyzed, the authors can conclude that Russia's attitude toward the BRI is generally positive. It is looked upon as an opportunity laden with manageable risks. Russia is far less preoccupied with issues of global governance, as applied to the BRI, than with the initiative's real impact on Russia itself and its post-Soviet

51 "NOVATEK i Fond Shelkovogo Puti zakryli sdelku po prodazhe doli v 'Yamal SPG'," Novatek, accessed May 17, 2019, http://www.novatek.ru/en/press/releases/index.php?id_4=1165.

52 “China lenders provide \$12 bln. loan for Russia’s Yamal LNG project-sources," UK Reiters, accessed May 18, 2019, https://uk.reuters.com/article/russia-china-yamal/china-lenders-provide-12-blnloan-for-russias-yamal-lng-project-sources-idUKL2N17V2MI.

53 “Major events: 2014, history of the company," CNPC.COM.CN, accessed May 18, 2019, https://www.cnpc.com.cn/en/majorevents/201507/b63990686b4b4d6bbf6081c97a80ddc1.shtml.

54 “10\% stake in SIBUR to be sold to China's Silk Road Fund," SIBUR, accessed May 18, 2019, https:/www.sibur.ru/en/press-center/news/10stakeinSIBURtobesoldtoChinasSilkRoadFund/. 
neighborhood. ${ }^{55}$ There, Moscow is focused on finding a model of engagement that, while benefiting Russia economically, would protect Russia's national sovereignty and its security interests. Russians also realize that the BRI is a political project geared to bolster the stature of President Xi Jinping. The Russian public opinion is willing to express support, conscious that it is Putin-Xi relationship the key element of the Russian-Chinese partnership. The Belt permits Russia to diversify its economic latitude over both Chinese-initiated economic integration blocs and Western ones in the possible future.

Рукопись поступила: 28 мая 2019 г.

Submitted: 28 May 2019

\section{References}

Kolosov, V.A., Zotova, M.V., Popov, F.A., Gritsenko, A.A., and Sebentsov, A.B. "Postsovetskoye pogranich'ye Rossii mezhdu Vostokom i Zapadom (analiz politicheskogo diskursa)." Polis. Political Studies Journal, no. 5 (2018): 57-69 (in Russian).

$\mathrm{Li}$, Na. "Initsiativa 'odin poyas, odin put' kak novaya model' sotrudnichestva KNR s Rossiyey i stranami Tsentral'noy Azii.” RUDN Journal of World History 10, no. 4 (2018): 382-392 (in Russian).

Luzyanin, S.G. " 'Odin poyas, odin put':' rossiyskaya proyektsiya i problemy sopryazheniya." In Kitay v mirovoy i regional'noy politike. Istoriya i sovremennost', 27-37. Moscow: IDV RAN Publ., 2017 (in Russian).

Luzyanin, S.G., and Larin, A.G. "Problema kitayskikh migrantov v Rossii v kontekste sopryazheniya "YEAES - Shelkovyy put'." In Kitay vmirovoy i regional'noy politike. Istoriya i sovremennost', 64-76. Moscow: IDV RAN Publ., 2017 (in Russian).

Makarov, I.A., and Sokolova, A.K. "Sopryazheniye yevraziyskoy integratsii i Ekonomicheskogo poyasa Shelkovogo puti: vozmozhnosti dlya Rossii." International Organizations Research Journal 11, no. 2 (2016): 40-57 (in Russian).

Mastepanov, A., and Tomberg, I. "Kitay diktuyet energeticheskuyu politiku XXI v." International Trends 16, no. 3 (2018): 6-38 (in Russian).

Mosyakov, D.V. "Novaya i noveyshaya istoriya. Modernizatsiya i globalizatsiya vostochnykh obshchestv." International Trends 15, no. 3 (2016): 103-106 (in Russian).

Mitchell, G. "China in Central Asia: The beginning of the end for Russia?" Slovo 26, no. 1 (2014): $18-31$.

James, Sherr. "How to Suborn Great Powers." Asia Policy, no. 16 (2013): 164-167.

Tertri, D. "Russkiy vopros v postsovetskiy period." Vestnik of Saint Petersburg University. History 62, no. 1 (2017): 43-56 (in Russian).

\section{Библиографический список}

Ли На. Инициатива «один пояс, один путь» как новая модель сотрудничества КНР с Россией и странами Центральной Азии // Вестник Российского университета дружбы народов. Серия: Всеобщая история. 2018. Т. 10. № 4. С. 382-392.

Лузянин С.Г. «Один пояс, один путь»: российская проекция и проблемы сопряжения // Китай в мировой и региональной политике. История и современность. М.: ИДВ РАН, 2017. C. $27-37$.

Лузянин С.Г., Ларин А.Г. Проблема китайских мигрантов в России в контексте сопряжения «ЕАЭС - Шелковый путь» // Китай в мировой и региональной политике. История и современность. М.: ИДВ РАН, 2017. С. 64-76.

55 A. Gabuev, "Kak Shelkovyy put' stal rezinovym," Vedomosti, accessed May 18, 2019, https:// www.vedomosti.ru/opinion/articles/2018/09/04/779827-shelkovii-put. 
Колосов В.А., Зотова М.В., Попов Ф.А., Гриценко А.А., Себенцов А.Б. Постсоветское пограничье России между Востоком и Западом (анализ политического дискурса) // Полис. Политические исследования. 2018. № 5. С. 57-69.

Макаров И.А., Соколова А.К. Сопряжение евразийской интеграции и Экономического пояса Шелкового пути: возможности для России // Вестник международных организаций. 2016. T. 11. № 2. С. 40-57.

Мастепанов А., Томберг И. Китай диктует энергетическую политику XXI в. // Международные процессы. 2018. Т. 16. № 3. С. 6-38.

Мосяков Д.В. Новая и новейшая история. Модернизация и глобализация восточных обществ // Международные процессы. 2016. Т. 15. № 3. С. 103-106.

Тертри Д. Русский вопрос в постсоветский период // Вестник СПбГУ. История. 2017. Т. 62. № 1. C. 43-56.

James Sherr. How to Suborn Great Powers // Asia Policy. 2013. № 16. P. 164-167.

Mitchell G. China in Central Asia: The beginning of the end for Russia? // Slovo. 2014. Vol. 26. №. 1. P. 18-31.

\section{Информация об авторах / Information about the authors}

Мартыненко Станислав Евгеньевич, кандидат исторических наук, ассистент кафедры теории и истории международных отношений Российского университета дружбы народов.

Пархитько Николай Петрович, кандидат исторических наук, доцент кафедры теории и истории журналистики Российского университета дружбы народов.
Stanislav E. Martynenko, Kandidat istoricheskikh nauk [Ph.D. in History], Assistant at the Department of Theory and History of International Relations, RUDN University.

Nickolay P. Parkhitko, Kandidat istoricheskikh nauk [Ph.D. in History], Associate Professor at the Department of Theory and History of Journalism, RUDN University. 